\title{
The UTAUT Model Analysis in the Technology Use of Generation-Z Users in Cambodia during COVID-19 Situation
}

\author{
Ubonwan Suwannapusit $^{1}$, Tokla Moeut ${ }^{2}$, Leap Heng Pheap ${ }^{3}$, Ampol Chayomchai ${ }^{4}$ \\ ${ }^{1}$ Lecturer, Faculty of Management Sciences, Surindra Rajabhat University, Surin, THAILAND \\ ${ }^{2}$ Teacher, Hun Sen Wat Svay High School, Siem Reap, CAMBODIA \\ ${ }^{3}$ Independent Researcher, Battambang, CAMBODIA \\ ${ }^{4}$ Lecturer, Faculty of Management Science, Phetchabun Rajabhat University, Phetchabun, THAILAND
}

\begin{abstract}
Due to the widespread infection of the coronavirus (COVID-19) over the world, people were forced to stay at home, and technology has been increasingly used in communication, entertainment, and work. This research emphasized the study on the technology usage of Generation $\mathrm{Z}$ who are ready and highly skilled in using technology. The purpose of the study was to investigate the influence of key factors affecting the intended use and practical application of Generation $\mathrm{Z}$ technology in Cambodia during the COVID-19 pandemic. The researcher chose to use the UTAUT Model to test the research hypothesis. A questionnaire is a research tool used to collect data online. It was found that the sample size was 212 respondents. Descriptive analysis and the partial least square structural equation model (PLS-SEM) evaluation were performed. The results revealed that (1) most of the respondents were male, had under a bachelor's degree, and monthly income was equal to or more than 312 US dollars, (2) the performance expectancy significantly influenced the behavioral intention, but effort expectancy, social influence, and facilitating conditions did not affect the behavioral intention of technology use, and (3) the behavioral intention to use technologies significantly influenced the actual use behavior during the covid-19 situation. This study suggests that technology organizations or businesses should pay attention to the potential benefits of technology for spurring the technology adoption and use of Generation Z people in Cambodia.
\end{abstract}

KEYWORDS: Cambodia, Covid-19, Generation-Z, Technology Use, UTAUT Model

\section{INTRODUCTION}

The spread and spread of the coronavirus (COVID-19) around the world has a huge impact on human life. The effects of this disease are many, including social, health, medical, political, travel, lifestyle, interactions, family conditions, work in both the public and private sectors. And no matter which country in the world, they all suffer from this disease similarly, which is considered a global disease. All countries in the affected countries are seeking ways to contain the outbreak, including basic measures such as wearing a mask, washing hands with alcohol, and social distancing. It also includes the use of vaccines for disease prevention and control. Official statistics to date show that the number of people infected worldwide exceeds 170 million (World Health Organization, 2021a). Common measures for controlling this disease are self-quarantining at home, working from home, wearing a mask, washing hands with alcohol, and social distancing. Cambodia is one of the countries where the disease has been found but is still under control. Non-pharmaceutical intervention and management of the disease have been used, such as wearing a mask, washing hands, closing schools and work, and staying at home, which is considered government control (World Health Organization, 2021b). With home quarantines, people are more likely to use technology to communicate, have fun, reduce stress, learn, play games, and use social media. Especially in Generation $\mathrm{Z}$ who have high technological abilities and skills and often have communication tools or mobile phones used in daily life all the time (Betz, 2019; Duzenli, et al., 2019; Gaidhani, et al., 2019). This Generation Z has markedly different abilities and skills from the previous generation, especially computer and technology talents and skills (Gaidhani, et al., 2019). For that reason, it can be considered that Generation $\mathrm{Z}$ is a business target in technology marketing. Business organizations need to understand various aspects of Generation $\mathrm{Z}$, including their perspectives, thoughts, attitudes, and daily behaviors (Boakye \& Meng, 2019). This research aims to study the use of Generation Z technology during the COVID-19 pandemic. The researcher selected the UTAUT (Unified theory of acceptance and use of technology) Model, which involved important factors in the use of technology. The researcher expects that the research results will be beneficial to organizations both government and 


\section{International Journal of Current Science Research and Review}

ISSN: 2581-8341

Volume 04 Issue 07 July 2021

DOI: 10.47191/ijcsrr/V4-i7-06, Impact Factor: 5.825

IJCSRR@ 2021

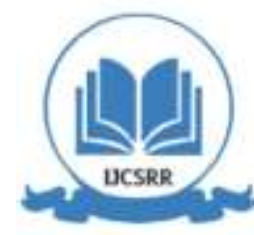

www.ijcsrr.org

business in understanding the key factors in choosing Generation $\mathrm{Z}$ technology, which is considered a new generation of country and world

\section{LITERATURE REVIEW}

In this study, we used the UTAUT Model to describe the phenomena and behavior of the research population, which refers to Generation $\mathrm{Z}$ who use technology in their daily lives all the time. This model was developed from several other models such as the Technology acceptance model (TAM), Theory of reasoned action (TRA), Theory of planned behavior (TPB) for the purpose of researching the acceptance and use of the technology of the study group (Abrahao, et al., 2016; Venkatesh, et al., 2016). The UTAUT model was developed by Venkatesh, Morris, Davis, and Davis in 2003 which links to the technology acceptance and use behaviors from various perspectives (Bervell \& Umar, 2017; Venkatesh, et al., 2016). The model consists of six key factors including performance expectancy, effort expectancy, social influence, facilitating conditions, behavioral intention, and use behavior of technology. It shows that four factors: performance expectancy, effort expectancy, social influence, and facilitating conditions influence behavioral intention to adopt the technology. And two key factors: behavioral intention and facilitating conditions influence the use behavior of technology (Abrahao, et al., 2016; Venkatesh, et al., 2016). Performance expectancy is the expectation and belief that technology choice will affect the effectiveness of the user experience (Abrahao, et al., 2016) while effort expectancy is the expectation of the ease of use of the technology chosen by the user (Chao, 2019; Venkatesh, et al., 2016). Another key factor is the social influence that means people are convinced by others who believe in the benefit of technology (Tan, 2013; Venkatesh, et al., 2016) while facilitating condition means organizational supports in the technologies use (Bervell \& Umar, 2017; Venkatesh, et al., 2016). From The UTAUT model, it shows the direct influence of performance expectancy, effort expectancy, and social factor on the behavioral intention of technology choice or utilization (Bervell \& Umar, 2017; Salim, 2012; Tan, 2013; Venkatesh, et al., 2016) while facilitating condition directly influence both behavioral intention of technology use and the actual use behavior of technology (Bervell \& Umar, 2017; Venkatesh, et al., 2016).

Many previous studies support the effect of performance expectancy and effort expectancy on the behavioral intention of technology utilization (Catherine, Geofrey, Moya, \& Aballo, 2017; Chao, 2019; Tan, 2013; Sair \& Danish, 2018). The study of Sair and Danish (2018) indicated that performance expectancy and effort expectancy significantly affected the behavioral intention of technology use in mobile commerce customers. The study of Catherine, et al. (2017) found the effects of performance expectancy and effort expectancy on the behavioral intention of banking technology. However, the study of Mensah (2019) found that performance expectancy and effort expectancy did not affect the behavioral intention of e-government services. Also, it found that previous studies concluded the effect of social influence on the behavioral intention in using technology (Abrahao, et al., 2016; Catherine, Geofrey, Moya, \& Aballo, 2017; Tan, 2013). The study of Abrahao, et al. (2016) and Tan (2013) pointed out social the effect of social influence on the behavioral intention of users in technology choices. The study of Catherine, et al. (2017) found the influence of social influence on the behavioral intention of e-banking business. However, the study of Bervell and Umar (2017) and Mensah (2019) showed that the social influence did not affect the behavioral intention of technology use. In addition, previous studies also revealed the influence of facilitating conditions on technology use (Catherine, Geofrey, Moya, \& Aballo, 2017). The study of Catherine, et al. (2017) found the effects of facilitating conditions on the behavioral intention of banking technology. And the study of Mensah (2019) found that facilitating conditions significantly affected the behavioral intention of e-government services. However, the study of Zhou, et al., (2019) found that the facilitating conditions did not affect the technology choices. Finally, the UTAUT model showed the effect of the behavioral intention on the actual use behavior in technology choice. Many previous studies showed that the behavioral intention in using technology affected the actual use behavior of technology choices (Bervell \& Umar, 2017; Tan, 2013; Venkatesh, et al., 2016; Zhou, et al., 2019). The study of Zhou, et al. (2019) indicated that higher behavioral intention of technology choices would significantly influence the use of technology. This consistent with the study of Tan (2013) who found that the behavioral intention affected the use behavior of technology choice and the study of Kurt and Tingoy (2017) who concluded that the behavioral intention influenced the actual use behavior of technology in UK users.

\section{CONCEPTUAL FRAMEWORK}

From the literature review and related research in the past, the researcher summarizes the framework of the research as shown in Figure one, with a total of six hypotheses. 


\section{International Journal of Current Science Research and Review}

ISSN: 2581-8341

Volume 04 Issue 07 July 2021

DOI: 10.47191/ijcsrr/V4-i7-06, Impact Factor: 5.825

IJCSRR@ 2021

www.ijesrr.org

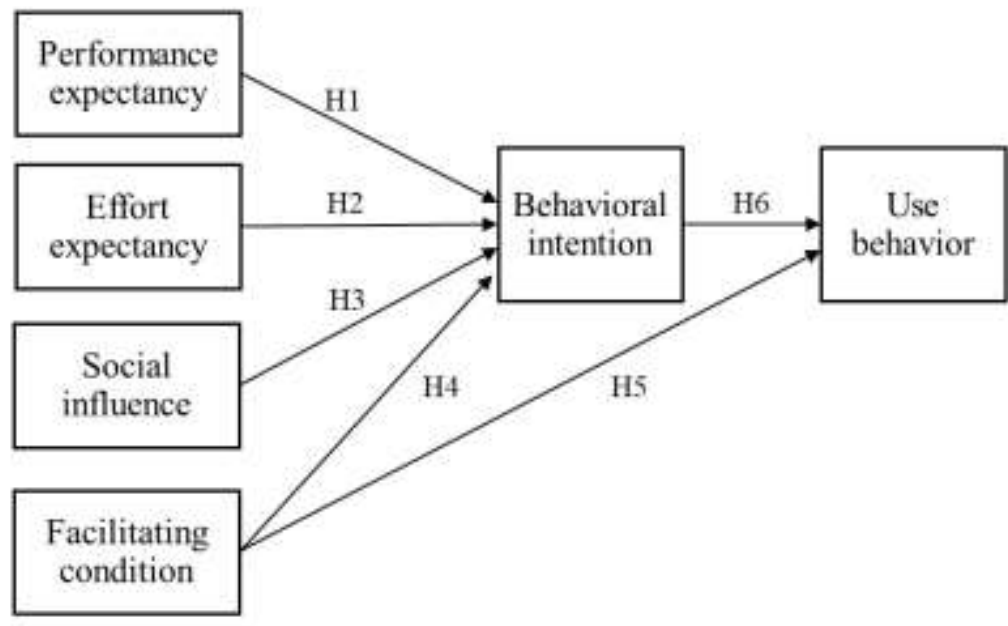

Figure 1. Conceptual framework

H1: Performance expectancy significantly affect the behavioral intention of technology use

H2: Effort expectancy significantly affect the behavioral intention of technology use

H3: Social influence significantly affect the behavioral intention of technology use

H4: Facilitating condition significantly affect the behavioral intention of technology use

H5: Facilitating condition significantly affect the use behavior of technology

H6: Behavioral intention of technology use significantly affect the use behavior of technology

\section{RESEARCH METHODOLOGY}

\section{Population and sample}

The population of this study was Generation $\mathrm{Z}$ people who used technology during the COVID-19 pandemic. This may be the use of technology during home quarantine or work from home. It may be the use of social media, the use of mobile applications, the use of computer programs or the use of the Internet to work or personal. This population designation means that the exact number is unknown. Therefore, the researcher collected data by online media channels which received a number of questionnaires that were actually two hundred and twelve.

\section{Research tool}

The research used a questionnaire as a research tool by developing questions from research related to the UTAUT model (Table 1). The first part of questionnaire was for demographic data (age, education, income per month), and the second part was about key variables in the research framework included performance expectancy, effort expectancy, social influence, facilitating conditions, behavioral intention, and use behavior of the technology. The questionnaire used 10 points scale (totally disagree=1 to totally agree $=10$ ) to measure those key variables. The reliability test results of the questionnaire by Cronbach's alpha statistic were between 0.77-0.92 as shown in Table 1. This result indicated that there was good reliability (Hair, et al., 2014).

Table 1. Research questionnaire and reliability test result

\begin{tabular}{|c|c|c|c|}
\hline Variables & Measures & References & $\begin{array}{l}\text { Cronbach } \\
\text { Alpha }\end{array}$ \\
\hline $\begin{array}{ll}\text { Performance } & \text { expectancy } \\
(\text { PERFORM) } & \end{array}$ & Per1, Per2, Per3, Per4, Per5 & \multirow{3}{*}{$\begin{array}{l}\text { Venkatesh et al. (2003); Khechine et al. } \\
\text { (2014); Salim (2012) }\end{array}$} & 0.87 \\
\hline Effort expectancy (EFFORT) & Eff1, Eff2, Eff3, Eff4 & & 0.77 \\
\hline Social Influence (SOCIAL) & Soc1, Soc2, Soc3, Soc4 & & 0.88 \\
\hline
\end{tabular}




\section{International Journal of Current Science Research and Review}

ISSN: 2581-8341

Volume 04 Issue 07 July 2021

DOI: 10.47191/ijcsrr/V4-i7-06, Impact Factor: 5.825

IJCSRR@ 2021

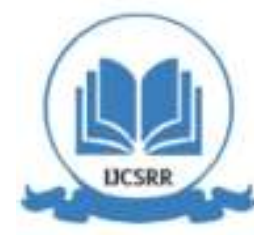

www.ijcsrr.org

\begin{tabular}{|l|l|l|l|}
\hline Facilitating condition (FACIL) & Fac1, Fac2, Fac3, Fac4 & $\begin{array}{l}\text { Venkatesh et al. (2003); Khechine et al. } \\
(2014)\end{array}$ & 0.78 \\
\cline { 1 - 2 } Behavioral intention (INTENT) & Int1, Int2, Int3, Int4 & $\begin{array}{l}\text { Venkatesh et al. (2003); Khechine et al. } \\
(2014)\end{array}$ & 0.92 \\
\cline { 1 - 2 } Use behavior (USE) & Use1, Use2, Use3, Use4 & 0.91 \\
\hline
\end{tabular}

\section{Statistical Analysis}

The study analyzed descriptive statistics by using frequency, percentage, mean, standard deviation, skewness, and kurtosis. The basic statistical analysis of the research was done by the SPSS program. As for inferential analysis, the study analyzed the PLS Structural Equation model (Partial Least Square-Structural Equations Model) with the SmartPLS 2.0 M3 program. The first part of the analysis of measurement models used three main statistics: the Average Variance Estimates (AVE), Composite Reliability (CR), and Cronbach's Alpha. The second part was the structural equation model analysis to test research hypotheses (Ringle, et al., 2015). The study evaluated the model by beta coefficients, the significance of $t$-statistics, and coefficient of determination $\left(\mathrm{R}^{2}\right)$. For the model evaluation, the researcher used 5000 samples of the bootstrapping procedure for this step (Hair et al., 2017).

\section{RESEARCH RESULTS}

\section{Descriptive analysis}

The data included in the calculations and statistical analysis of this study amounted to 212 . The descriptive analysis results are shown in the second table. The male number was 117 (55.2\%) and the female number was 95 (44.8\%). Most of the participants had less than a bachelor's degree, which numbered 103 (48.6\%). And most participants earned equal to or more than 312 US dollars per month, which numbered $116(54.7 \%)$.

Table 2. Results of descriptive analysis

\begin{tabular}{|l|l|l|l|}
\hline Variables & Frequencies & Percent \\
\hline \multirow{3}{*}{ Gender } & Male & 117 & 55.2 \\
\cline { 2 - 4 } & Female & 95 & 44.8 \\
\hline \multirow{4}{*}{ Education } & Below Bachelor degree & 103 & 48.6 \\
\cline { 2 - 4 } & Bachelor degree & 95 & 44.8 \\
\cline { 2 - 4 } & Above Bachelor degree & 14 & 6.6 \\
\hline \multirow{2}{*}{ Income per month } & Less than 312 USD & 96 & 45.3 \\
\cline { 2 - 4 } & 312 USD or more & 116 & 54.7 \\
\hline
\end{tabular}

Source: Authors' own research results.

The third table shows the results of the descriptive analysis of the key variables in this study. It was found that the respondents' opinions in four variables were: performance expectancy, effort expectancy, behavioral intention, and use behavior, have a high level. The other two variables: social influence and facilitating conditions were moderately average. In addition, it was found that the skewness and dominance of the data showed normal curvature (Hair et al., 2014). Therefore, the data is well suited for further inferential analysis.

Table 3. Statistical analysis of key variables

\begin{tabular}{|l|l|l|l|l|}
\hline Variables & Means & Standard Deviation & Skewness & Kurtosis \\
\hline Performance expectancy (Perform) & 7.48 & 1.51 & -0.47 & 0.19 \\
\hline Effort expectancy (Effort) & 7.31 & 1.56 & -0.36 & -0.03 \\
\hline Social influence (Social) & 5.88 & 1.79 & -0.03 & -0.26 \\
\hline Facilitating condition (Facill) & 6.81 & 1.55 & -0.20 & 0.36 \\
\hline Behavioral Intention (Intent) & 7.16 & 1.58 & -0.33 & -0.25 \\
\hline Use behavior (Use) & 7.30 & 1.52 & -0.29 & -0.03 \\
\hline
\end{tabular}

Source: Authors' own research results. 


\section{International Journal of Current Science Research and Review}

ISSN: 2581-8341

Volume 04 Issue 07 July 2021

DOI: 10.47191/ijcsrr/V4-i7-06, Impact Factor: 5.825

IJCSRR@ 2021

www.ijesrr.org

\section{Assessment of measurement model}

The fourth table shows the results from the analysis of the measurement model. First, the researcher assessed the loading weight with the acceptable values greater than 0.7 (Hair et al., 2017). The results showed that all data exceeded the criteria used. Second, the researcher considered the Cronbach's Alpha and composite reliability of the data where the acceptable threshold must also exceed 0.7 (Hair et al., 2017). The results showed that all data exceeded the threshold. Finally, the researchers examined the Average Variance Extracted (AVE) value using an acceptable value of 0.5, with the results found that all data exceeded that threshold (Hair et al., 2017). In conclusion, the measurement model is appropriate and the researcher can further analyze the structural model to prove the research hypothesis.

Table 4. Validity and reliability of measurement model

\begin{tabular}{|c|c|c|c|c|c|}
\hline Constructs & Items & Loading & Cronbach's Alpha & $\begin{array}{l}\text { Composite } \\
\text { Reliability (CR) }\end{array}$ & $\begin{array}{l}\text { Average Variance Extracted } \\
\text { (AVE) }\end{array}$ \\
\hline $\begin{array}{l}\text { Performance } \\
\text { expectancy } \\
\text { (Perform) }\end{array}$ & $\begin{array}{l}\text { Perf1, } \\
\text { Perf2, } \\
\text { Perf3, } \\
\text { Perf4, } \\
\text { Perf5 }\end{array}$ & $\begin{array}{l}0.809 \\
0.847 \\
0.873 \\
0.841 \\
0.873\end{array}$ & 0.903 & 0.928 & 0.721 \\
\hline $\begin{array}{l}\text { Effort } \\
\text { expectancy } \\
\text { (Effort) }\end{array}$ & $\begin{array}{l}\text { Effo1, } \\
\text { Effo2, } \\
\text { Effo3, } \\
\text { Effo4 }\end{array}$ & $\begin{array}{l}0.700 \\
0.843 \\
0.829 \\
0.804\end{array}$ & 0.805 & 0.873 & 0.634 \\
\hline $\begin{array}{l}\text { Social } \\
\text { influence } \\
\text { (Social) }\end{array}$ & $\begin{array}{l}\text { Soc1, } \\
\text { Soc2, } \\
\text { Soc3, } \\
\text { Soc4 }\end{array}$ & $\begin{array}{l}0.816 \\
0.823 \\
0.500 \\
0.793\end{array}$ & 0.739 & 0.829 & 0.556 \\
\hline $\begin{array}{l}\text { Facilitating } \\
\text { condition } \\
\text { (Facill) }\end{array}$ & $\begin{array}{l}\text { Sup1, } \\
\text { Sup2, } \\
\text { Sup3, } \\
\text { Sup4 }\end{array}$ & $\begin{array}{l}0.813 \\
0.837 \\
0.851 \\
0.844\end{array}$ & 0.858 & 0.903 & 0.700 \\
\hline $\begin{array}{l}\text { Behavioral } \\
\text { Intention } \\
\text { (Intent) }\end{array}$ & $\begin{array}{l}\text { Intent } 1, \\
\text { Intent } 2, \\
\text { Intent } 3 \text {, } \\
\text { Intent } 4\end{array}$ & $\begin{array}{l}0.879 \\
0.875 \\
0.882 \\
0.872\end{array}$ & 0.900 & 0.930 & 0.769 \\
\hline $\begin{array}{l}\text { Use behavior } \\
\text { (Use) }\end{array}$ & $\begin{array}{l}\text { Use1, } \\
\text { Use2, } \\
\text { Use3, } \\
\text { Use4 }\end{array}$ & $\begin{array}{l}0.869 \\
0.884 \\
0.857 \\
0.875\end{array}$ & 0.895 & 0.927 & 0.759 \\
\hline
\end{tabular}

Source: Authors' own research results.

\section{Assessment of structural model}

The fifth and sixth tables and figures two and three show the results of the structural equation model analysis. The researcher used the PLS-SEM analysis technique to test the influence path based on the research hypothesis. Table five is a summary of all hypothetical influence paths, which reveals only two hypotheses accepted by the research: H1 and H6. The study accepted the first hypothesis, which found that performance expectancy had a significant influence on the behavioral intention of technology use, and the study accepted the sixth hypothesis, which also found a significant influence of the behavioral intention on the technology use behavior in Generation $\mathrm{Z}$ people. For other hypotheses, the study did not find the influence of the independent variable on the dependent variable. Therefore, the study concluded that the second, third, fourth, and fifth hypothesis was rejected. 
International Journal of Current Science Research and Review

ISSN: 2581-8341

Volume 04 Issue 07 July 2021

DOI: 10.47191/ijcsrr/V4-i7-06, Impact Factor: 5.825

IJCSRR@ 2021

www.ijcsrr.org

Table 5. Result of Structural analysis

\begin{tabular}{|l|l|l|l|l|l|l|}
\hline Relationship & $\begin{array}{l}\text { Standard } \\
\text { Beta }\end{array}$ & $\begin{array}{l}\text { Standard } \\
\text { Deviation }\end{array}$ & $\begin{array}{l}\text { Standar } \\
\text { d Error }\end{array}$ & $\begin{array}{l}\text { S } \\
\text { Statistics }\end{array}$ & $\begin{array}{l}\text { P } \\
\text { Values }\end{array}$ & Evaluation \\
\hline $\begin{array}{l}\text { Performance expectancy } \rightarrow \text { Intention } \\
(\mathrm{H} 1)\end{array}$ & 0.436 & 0.114 & 0.114 & 3.827 & $\begin{array}{l}< \\
0.05^{*}\end{array}$ & $\begin{array}{l}\text { Accepted } \\
\text { H1 }\end{array}$ \\
\hline Effort expectancy $\rightarrow$ Intention (H2) & 0.177 & 0.110 & 0.110 & 1.610 & $>0.05$ & $\begin{array}{l}\text { Rejected } \\
\text { H2 }\end{array}$ \\
\hline Social influence $\rightarrow$ Intention (H3) & 0.114 & 0.077 & 0.077 & 1.496 & $>0.05$ & $\begin{array}{l}\text { Rejected } \\
\text { H3 }\end{array}$ \\
\hline Facilitating condition $\rightarrow$ Intention (H4) & 0.166 & 0.130 & 0.130 & 1.270 & $>0.05$ & $\begin{array}{l}\text { Rejected } \\
\text { H4 }\end{array}$ \\
\hline Facilitating condition $\rightarrow$ Use (H5) & 0.031 & 0.049 & 0.049 & 0.633 & $>0.05$ & $\begin{array}{l}\text { Rejected } \\
\text { H5 }\end{array}$ \\
\hline Intention $\rightarrow$ Use (H6) & 0.924 & 0.037 & 0.037 & 25.156 & $\begin{array}{l}< \\
0.05^{*}\end{array}$ \\
\hline
\end{tabular}

Notes: * means the statistical significance at 0.05 level

Source: Authors' own research results.

Figures two and three show the structural model analysis results in visual paths between variables. The second figure is the result of the Bootstrapping analysis which obtained the t-statistic and significance. The results of the analysis concluded that the first (H1: performance expectancy [Perform] $\rightarrow$ Behavioral intention [Intent]) and sixth (H6: Behavioral intention [Intent] $\rightarrow$ Use behavior [Use]) hypothesis were accepted.

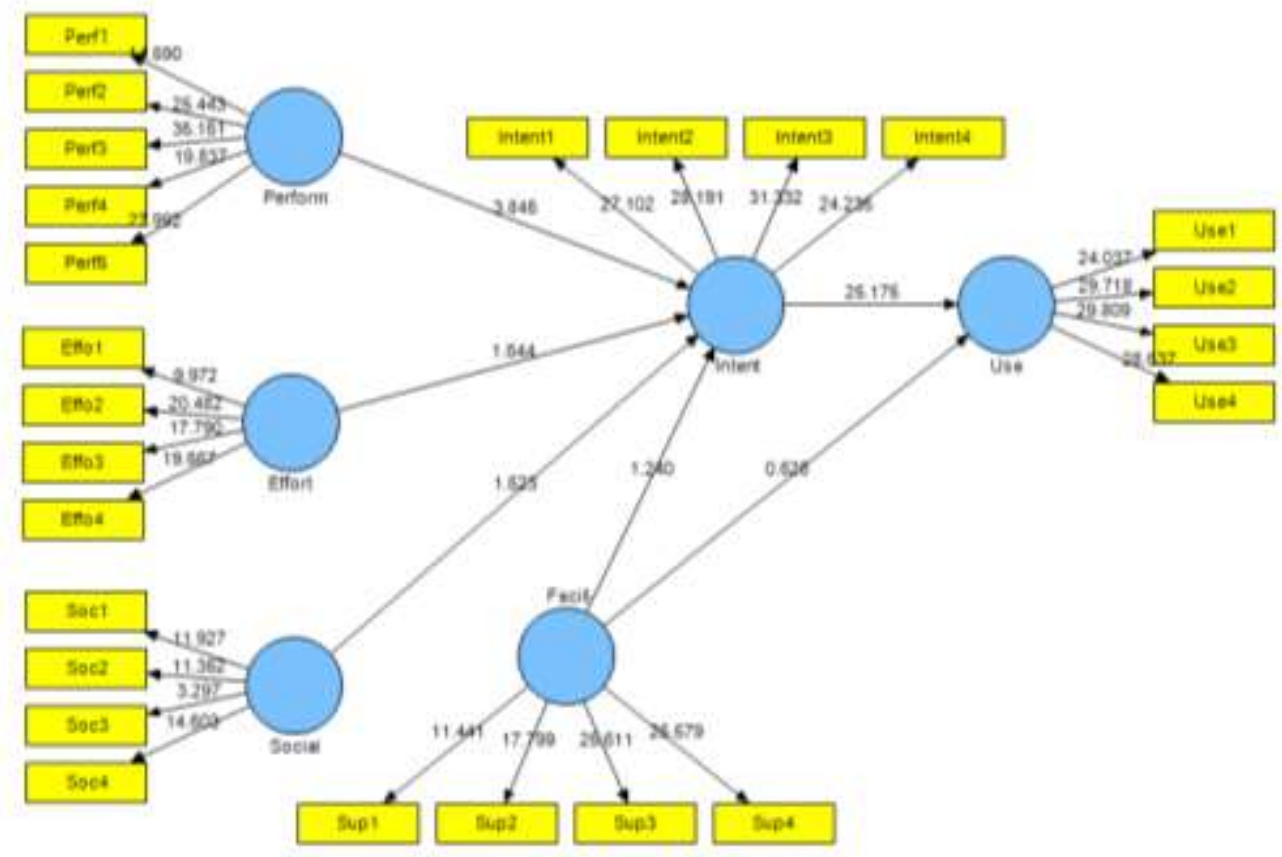

Figure 2. Bootstrapped PLS-SEM model

Source: Authors' own research results. 


\section{International Journal of Current Science Research and Review}

ISSN: 2581-8341

Volume 04 Issue 07 July 2021

DOI: 10.47191/ijcsrr/V4-i7-06, Impact Factor: 5.825

IJCSRR@ 2021

www.ijcsrr.org

The third figure shows path coefficients, loading weights, and the coefficients of determination $\left(\mathrm{R}^{2}\right)$. It was found that the most valuable path was the influence path of performance expectancy on the behavioral intention with a coefficient of 0.924 , followed by the path of the behavioral intention on the use behavior with a coefficient of 0.436 .

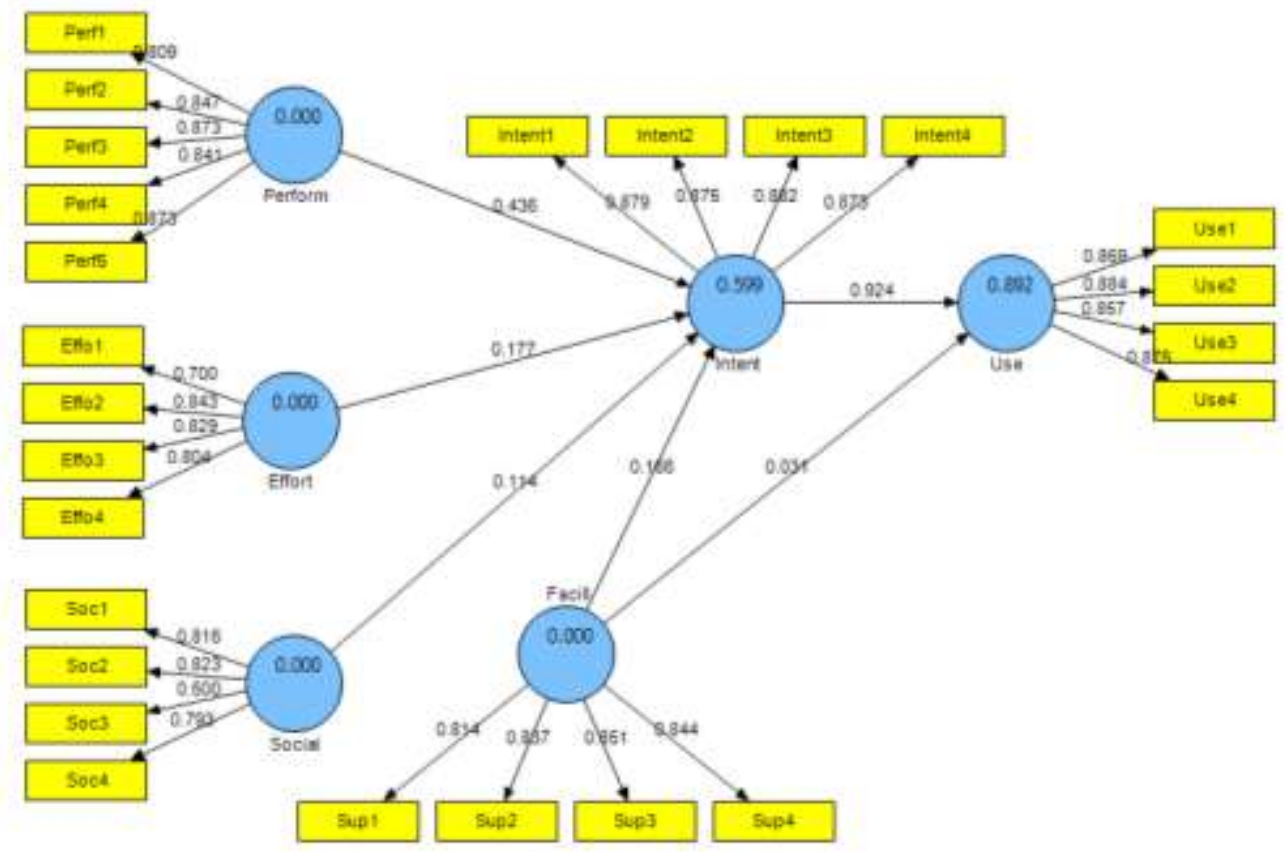

Figure 3..Final PLS-SEM model

Source: Authors' own research results.

The sixth table is the conclusion of coefficients of determination $\left(\mathrm{R}^{2}\right)$. It found that the behavioral intention and facilitating conditions could describe the variance of the use behavior by $89.2 \%$. In addition, the performance expectancy, effort expectancy, social influence, and facilitating conditions together describe the variance of the behavioral intention by $59.9 \%$.

Table 6. Coefficient of Determination

\begin{tabular}{|l|l|}
\hline Dependent variables (Symbols) & R Square \\
\hline Behavioral intention (Intent) & 0.599 \\
\hline Use behavior (Use) & 0.892 \\
\hline
\end{tabular}

Source: Authors' own research results.

\section{DISCUSSION AND CONCLUSION}

This research examined the influence of key factors affecting behavioral intentions and use behaviors in the technology of Cambodian Generation Z people during COVID-19. The study found that participants gave a high level of opinion on four factors: performance expectancy, effort expectancy, behavioral intention, and use behavior. The results show that Generation Z Cambodians are more interested in the usefulness and ease of use of technology during the COVID-19 pandemic, which requires more time at home. A study on the influence of key factors on behavioral intentions in using technology in Cambodian Generation $\mathrm{Z}$ people found that performance expectancy significantly affected behavioral intention. This finding was consistent with previous studies included the study of Sair and Danish (2018) who found that performance expectancy significantly influenced the behavioral intention of technology use, and the study of Catherine, et al. (2017) who indicated the significant effect of performance expectancy on the behavioral intention. And this study revealed the significant influence of the behavioral intention of technology use on the technology use behavior in Generation Z Cambodian. This finding was consistent with many studies included the study of Tan (2013) who found 


\section{International Journal of Current Science Research and Review}

ISSN: 2581-8341

Volume 04 Issue 07 July 2021

DOI: 10.47191/ijcsrr/V4-i7-06, Impact Factor: 5.825

IJCSRR@ 2021

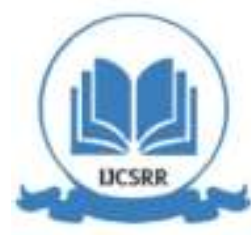

www.ijcsrr.org

that the behavioral intention influenced the use behavior of technology, the study of Kurt and Tingoy (2017) who found that the behavioral intention significantly affected the actual use behavior of technology, and the study of Zhou, et al. (2019) who pointed out that higher behavioral intention would influence the use behavior of technology choices. This finding was not consistent with the study of Zhou, et al., (2019) who found that the facilitating conditions did not affect the technology choices. In addition, the research found no influence of effort expectancy, social influence, and facilitating conditions on the behavioral intention of technology use, which was consistent with the study of Mensah (2019) who found that effort expectancy did not influence the behavioral intention and the studies of Bervell and Umar (2017) and Mensah (2019) showed that the social influence did not influence the behavioral intention of technology use. This finding was not consistent with some previous studies included the studies of Abrahao, et al. (2016) and Tan (2013) who found the effect of social influence on the behavioral intention of users in technology choices, and the study of Catherine, et al. (2017) who found the influence of social influence on the behavioral intention of the technology. The final research model is shown in Figure 4.

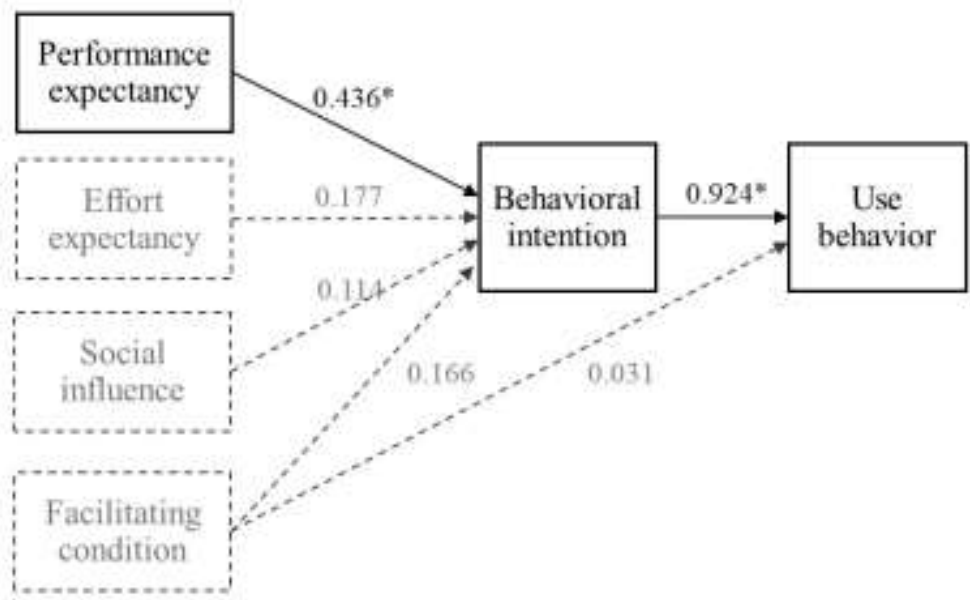

Figure 4. Final research model

\section{RECOMMENDATION}

The results of this study suggest that organizations involved in the adoption of technology for Generation $\mathrm{Z}$ should focus on the benefits of technology. This is because Generation Z Cambodians are interested in the benefits of technology that will influence their intentions to use the technology and their decision to implement it. However, the findings did not find the influence of three key factors, effort expectancy, social influence, and facilitating conditions, on behavioral intentions and use of technology among these groups. Therefore, future research should explore more on these issues to clarify the decision-making process of technology choices in Generation Z people in Cambodia.

\section{REFERENCES}

1. Abrahao, R. S., Moriguchi, S. N., \& Andrade, D. F. (2016). Intention of adoption of mobile payment: An analysis in the light of the unified theory of acceptance and use of technology (UTAUT). Revista de Administracao e Inovacao, 13, 221230.

2. Betz, C. L. (2019). Generations X, Y, and Z. Journal of Pediatric Nursing, 44, A7-A8.

3. Bervell, B., \& Umar, I. N. (2017). Validation of the UTAUT model: Re-considering non-linear relationships of exogenous variables in higher education technology acceptance research. EURASIA Journal of Mathematics Science and Technology Education, 13(10), 6471-6490.

4. Boakye, E. A. \& Meng, Q. (2019). Service quality and customer loyalty in the Ghanaian banking sector: The mediating role of customer satisfaction. International Journal of Business and Management Invention, 8(8), 78-84.

5. Catherine, N., Geofrey, K. M., Moya, M. B., \& Aballo, G. (2017). Effort expectancy, performance expectancy, social influence and facilitating conditions as predictors of behavioral intentions to use atms with fingerprint authentication in Ugandan banks, Global Journal of Computer Science and Technology: E-Network, Web \& Security, 17(5), 5-22. 


\section{International Journal of Current Science Research and Review}

ISSN: 2581-8341

Volume 04 Issue 07 July 2021

DOI: 10.47191/ijcsrr/V4-i7-06, Impact Factor: 5.825

IJCSRR@ 2021

www.ijesrr.org

6. Chao, C. M. (2019). Factors determining the behavioral intention to use mobile learning: An application and extension of the UTAUT model. Frontiers in Psychology, 10, 1-14.

7. Cochran, W. G., 1977. Sampling techniques. 3rd ed. New York: John Willey and Sons.

8. Duzenli, T., Alpak, E. M., \& Yilmaz, S. (2019). The correlation between urban open space occupation differences among generations X, Y, and Z occupant well-being. Applied Ecology and Environmental Research, 17(2), 3737-3751.

9. Gaidhani, S., Arora, L, \& Sharma, B. K. (2019). Understanding the attitude of generation Z towards workplace. International Journal of Management, Technology, and Engineering, 9(1), 2804-2812.

10. Hair, J. F., Black, W. C., Babin, B. J., \& Anderson, R. E., (2014). Multivaliate data analysis. $7^{\text {th }}$ ed. US: Pearson Education.

11. Hair, J. F., Hult, G. T. M., Ringle, C. M., \& Sarstedt, M. (2017). A primer on partial least squares structural equation modeling. ( $2^{\text {nd }}$ ed.). Thousand Oaks: Sage.

12. Khechine, H., Lakhal, S., Pascot, D., \& Bytha, A. (2014). UTAUT model for blended learning: The role of gender and age in the intention to use webinars. Interdisciplinary Journal of E-Learning and Learning Objects, 10, 33-52.

13. Kurt, O. E., \& Tingoy, O. (2017). The acceptance and use of a virtual learning environment in higher education: An empirical study in Turkey, and the UK. International Journal of Educational Technology in Higher Education, 14(26), 115.

14. Mensah, I. K. (2019). Factors influencing the intention of university students to adopt and use e-government services: An empirical evidence in China. SAGE Open, April-June, 1-19.

15. Ringle, C. M., Wende, S., \& Becker, J.-M. (2015). SmartPLS 3. Boenningstedt: SmartPLS GmbH, http://www.smartpls.com.

16. Sair, S. A., \& Danish, R. Q. (2018). Effect of performance expectancy and effort expectancy on the mobile commerce adoption intention through personal innovativeness among Pakistani consumers, Pakistan Journal of Commerce and Social Sciences, 12(2), 501-520.

17. Salim, B. (2012). An application of UTAUT model for acceptance of social media in Egypt: A statistical study. International Journal of Information Science, 2(6), 92-105.

18. Tan, P. J. B. (2013). Applying the UTAUT to understand factors affecting the use of English w-learning websites in Taiwan. SAGE Open, October-December, 1-12.

19. Venkatesh, V., Thong, J. Y. L., \& Xu, X. (2016). Unified theory of acceptance and use of technology: A synthesis and the road ahead. Journal of the Association for Information Systems, 17(5), 328-376.

20. World Health Organization. (2021a). Weekly epidemiological update on COVID-19 - 22 June 2021. Retrieved from https://www.who.int/publications/m/item/weekly-epidemiological-update-on-covid-19---22-june-2021

21. World Health Organization. (2021b). COVID-19 Joint WHO-MOH Situation Report 50 - 14 June 2021. Retrieved from https://www.who.int/cambodia/internal-publications-detail/covid-19-joint-who-moh-situation-report-50

22. Zhou, L. L., Owusu-Marfo, J., Antwi, H. A., Antwi, M. O., Kachie, A. D. T., \& Ampon-Wireko, S. (2019). Assessment of the social influence and facilitating conditions that support nurses' adoption of hospital electric information management systems (HEIMS) in Ghana: Using the unified theory of acceptance and use of technology (UTAUT) model. BMC Medical Informatics and Decision Making, 19, 1-9.

Cite this Article: Ubonwan Suwannapusit, Tokla Moeut, Leap Heng Pheap, Ampol Chayomchai (2021). The UTAUT Model Analysis in the Technology Use of Generation-Z Users in Cambodia during COVID-19 Situation. International Journal of Current Science Research and Review, 4(7), 651-659 